\title{
Phenotypic Plasticity Explains Response Patterns of European Beech (Fagus sylvatica L.) Saplings to Nitrogen Fertilization and Drought Events
}

\author{
Christoph Dziedek ${ }^{1}$, Andreas Fichtner ${ }^{1, *}$, Leonor Calvo ${ }^{2}$, Elena Marcos ${ }^{2}$, Kirstin Jansen ${ }^{1}$, \\ Matthias Kunz ${ }^{3}$, David Walmsley ${ }^{1}$, Goddert von Oheimb ${ }^{3}$ and Werner Härdtle ${ }^{1}$ \\ 1 Institute of Ecology, Leuphana University of Lüneburg, 21335 Lüneburg, Germany; \\ dziedek@uni-lueneburg.de (C.D.); kjansen@uni-lueneburg.de (K.J.); walmsley@uni-lueneburg.de (D.W.); \\ haerdtle@uni-lueneburg.de (W.H.) \\ 2 Faculty of Biological and Environmental Sciences, Ecology, University of León, 24071 León, Spain; \\ leonor.calvo@unileon.es (L.C.); elena.marcos@unileon.es (E.M.) \\ 3 Institute of General Ecology and Environmental Protection, Technische Universität Dresden, 01735 Tharandt, \\ Germany; matthias.kunz@tu-dresden.de (M.K.); goddert.von_oheimb@tu-dresden.de (G.V.O.) \\ * Correspondence: fichtner@uni-lueneburg.de; Tel.: +49-4131-6772-823; Fax: +49-4131-6772-808
}

Academic Editors: Fausto Manes, Lina Fusaro and Elisabetta Salvatori

Received: 6 February 2017; Accepted: 14 March 2017; Published: 20 March 2017

\begin{abstract}
Climate and atmospheric changes affect forest ecosystems worldwide, but little is known about the interactive effects of global change drivers on tree growth. In the present study, we analyzed single and combined effects of nitrogen $(\mathrm{N})$ fertilization and drought events $(\mathrm{D})$ on the growth of European beech (Fagus sylvatica L.) saplings in a greenhouse experiment. We quantified morphological and physiological responses to treatments for one- and two-year-old plants. $\mathrm{N}$ fertilization increased the saplings' aboveground biomass investments, making them more susceptible to D treatments. This was reflected by the highest tissue dieback in combined $\mathrm{N}$ and $\mathrm{D}$ treatments and a significant $\mathrm{N} \times \mathrm{D}$ interaction for leaf $\delta^{13} \mathrm{C}$ signatures. Thus, atmospheric $\mathrm{N}$ deposition can strengthen the drought sensitivity of beech saplings. One-year-old plants reacted more sensitively to $\mathrm{D}$ treatments than two-year-old plants (indicated by D-induced shifts in leaf $\delta^{13} \mathrm{C}$ signatures of one-year-old and two-year-old plants by $+0.5 \%$ and $-0.2 \%$, respectively), attributable to their higher shoot:root-ratios (1.8 and 1.2, respectively). In summary, the saplings' treatment responses were determined by their phenotypic plasticity (shifts in shoot:root-ratios), which in turn was a function of both the saplings' age (effects of allometric growth trajectories = apparent plasticity) and environmental impacts (effects of $\mathrm{N}$ fertilization = plastic allometry).
\end{abstract}

Keywords: allometric growth; apparent plasticity; $\delta^{13} \mathrm{C}$; global change; plastic allometry; shoot:root ratio

\section{Introduction}

Many ecosystems are currently subject to unprecedented shifts in environmental conditions on both regional and global scales [1]. This is true of forest ecosystems in particular, since trees are characterized by long life-cycles, and growth processes are mediated by the environment over centuries [2]. Among the currently active drivers of global change, climate and atmospheric changes (such as altered precipitation regimes and the deposition of reactive forms of nitrogen) have been shown to be amongst the major drivers of biodiversity loss and shifts in ecosystem functions [3]. Current climate projections assume rising mean annual temperatures, changing precipitation patterns, and shifts in the frequency and magnitude of extreme weather events (including more severe summer drought events [4]). In forest ecosystems, this may affect ecosystem functions such as primary 
production and carbon sequestration or the diversity and functional composition of tree species [5-7]. Atmospheric nitrogen $(\mathrm{N})$ deposition has tripled in the past century, with an upward trend expected for the coming decades [8,9]. Airborne $\mathrm{N}$ loads are considered to be responsible for enhanced radial increment of trees, but also for adverse effects on the biodiversity of forests $[10,11]$. While critically high loads of airborne $\mathrm{N}$ have affected ecosystem processes over the past decades, the impact of climate change is expected to increase in importance over the course of this century. This means that ecosystems which already have altered nitrogen levels are now subject to climate change, and both factors will continue to act upon ecosystems in the coming decades [12].

Although an increasing body of research has addressed ecosystem responses to environmental shifts by means of single-factor approaches, little is known about the interactive effects of co-occurring global change drivers and how these may affect ecosystem processes and services in the future [13,14]. It is, for example, conceivable that tree growth responses to climate change could be strengthened by the deposition of reactive forms of $\mathrm{N}$, probably due to fertilization effects on morphological traits such as shoot:root ratios ("plastic allometry" [15]). Thus, the extent to which climate shifts may alter tree growth patterns over time will depend on how $\mathrm{N}$ deposition will interact with climate warming or drought events [16]. Recent experiments have demonstrated that the combination of summer drought and $\mathrm{N}$ fertilization resulted in non-additive effects on plant growth and vitality [17-19]. As a consequence, $\mathrm{N}$-fertilized plants may exhibit higher drought sensitivity as compared to non-fertilized ones.

A further but—with regard to many tree species—not adequately considered factor influencing a plant species' response to environmental shifts is plant age. Many trees follow allometric growth trajectories that are characterized by age-related shifts in biomass allocation patterns ("partitioning"; $[15,20,21])$. This is reflected by traits such as shoot:root ratios, which are expected to decrease with increasing sapling age. As a consequence, a sapling's drought sensitivity may decrease with an age-related increase of belowground investments ("apparent plasticity" [15]). Thus, a tree's phenotypic plasticity (in terms of both plastic allometry and apparent plasticity) may influence its growth responses to environmental change [22].

In the present study, we analyzed growth responses of tree saplings to combined effects of $\mathrm{N}$ fertilization and drought events, taking Fagus sylvatica L. as an example. We focused on this tree species because Fagus sylvatica is the most abundant and dominating broad-leaved tree species in many parts of Western and Central Europe, and, therefore, is of particular importance from an ecological and economic point of view [23]. Although several studies have investigated the drought sensitivity of beech provenances along precipitation gradients in Central Europe and the Mediterranean region (for an overview see [24]), little is known about the drought sensitivity of beech populations of the south-western range margin (i.e., the Iberian Peninsula), an area that is considered one of the glacial refugia of Fagus sylvatica [25]). Since the genotypic plasticity and allelic richness of beech trees in this region are expected to be particularly high $[25,26]$, these populations may play an important role in the context of diversity conservation and the selection of proper genotypes for forestry under the prospect of a drier and warmer climate [24,27-29]. However, it remains unclear how sensitive these beech populations are in responding to co-occurring drivers of global change such as drought events and $\mathrm{N}$ deposition.

In the present study, we performed a two-year greenhouse experiment in which we altered the temporal combinations of $\mathrm{N}$ fertilization and summer drought, taking beech saplings originating from populations of the Cantabrian Mountain as an example. Specifically, we asked to what extent growth responses of tree saplings to single and combined effects of these drivers of global change were influenced by the saplings age (i.e., we compared the growth responses of one-year-old and two-year-old plants). Beech saplings were subjected to $\mathrm{N}$ fertilization in the first and second year of the experiment, but some of the $\mathrm{N}$-fertilized saplings were also exposed to drought events in the second year (i.e., drought took effect on already fertilized plants). Growth responses of saplings were measured in terms of morphological response variables (increment of height, stem diameter, and leaf biomass, 
total dry weight of aboveground and belowground biomass, tissue die-back) and physiological response variables (leaf $\mathrm{C}$ and $\mathrm{N}$ concentrations, leaf $\mathrm{C}: \mathrm{N}$ ratios, and leaf $\delta^{13} \mathrm{C}$ signatures as a proxy for the plants' intrinsic water use efficiency [30]). To test for age-related responses, we compared growth responses of one- and two-year-old plants. We hypothesized that (i) N-fertilized plants would exhibit higher drought sensitivity than non-fertilized plants; and (ii) one-year-old plants would be more sensitive to drought treatments than two-year-old plants.

\section{Materials and Methods}

\subsection{Seed Collection}

Fagus sylvatica seeds were collected across seven forest sites on north-facing slopes in the Cantabrian Mountains (NW Spain; Figure 1) in autumn 2009 (distances between sampling sites were 3-50 km; for forest site characteristics see Table S1 and Dziedek et al. [31]).

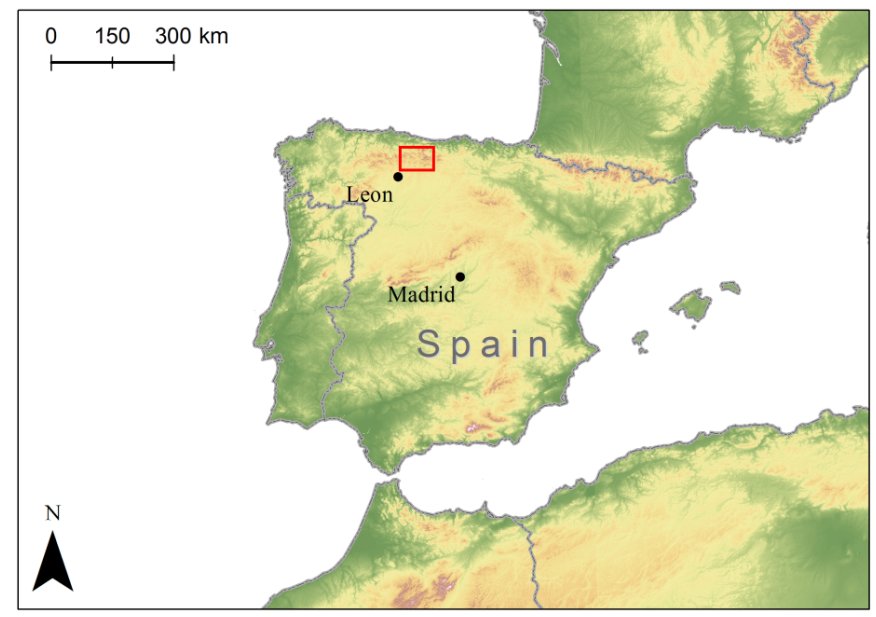

Figure 1. Location of the forest area in the Cantabrian Mountains (North Spain), in which seeds of beech trees were sampled (rectangle).

\subsection{Sapling Cultivation And Treatments}

The experiment was performed in a greenhouse at the Thünen-Institute (Hamburg, Germany) from spring 2010 to autumn 2011. After stratification in winter 2009/2010, seeds were raised in small pots (so-called "Jiffy Strips", Meyer KG, Rellingen, Germany) and seedlings were transplanted into circular plastic pots in May 2010 (one seedling per pot with 1 L of volume; cultivation substrate: TKS 2, Floragard, Oldenburg, Germany). In the second year of the experiment (2011), saplings were transplanted into circular $3 \mathrm{~L}$ plastic pots (one sapling per pot) to account for an increasing belowground biomass (cf. cultivation methods described by [24,31]).

In 2010, a total of 336 pots were randomly assigned to the two treatments applied in the first year: control and nitrogen treatment (i.e., 168 pots per treatment). In 2011, the pots from the 2010 control treatment were randomly assigned to a control and a drought treatment $(n=84$ pots in each new treatment). Similarly, the 168 pots from the 2010 nitrogen treatment were randomly assigned to a nitrogen treatment and a combined nitrogen-drought treatment performed in 2011. Thus, 84 pots, respectively, were subjected to four different treatments in 2011: control, nitrogen treatment, drought treatment, and a combined nitrogen-drought treatment (henceforth referred to as control, D, N, and ND treatment, respectively). Pots in the control and N treatment (applied in 2010 and 2011) were well watered during the experiment to avoid drought effects (ca. 40\% soil water content). Plants in the D and ND treatments were subjected to two drought periods (applied in 2011), during which no watering took place and the soil water content was reduced to ca. $10 \%$. Both drought periods lasted for about two weeks in June and August 2011 (the duration depended on the development of 
the pots' soil moisture, quantified by daily weighing during the $\mathrm{D}$ treatment). After $\mathrm{D}$ treatments, plants were again regularly watered (i.e., $40 \%$ soil water content). In the $\mathrm{N}$ and ND treatments, $\mathrm{N}$ was applied (as $\mathrm{NH}_{4} \mathrm{NO}_{3}$ ) in both study years in a quantity equivalent to $50 \mathrm{~kg} \cdot \mathrm{N} \cdot \mathrm{ha}^{-1} \cdot \mathrm{year}^{-1}$ (as solution in deionized water; corresponding to current maximum $\mathrm{N}$ deposition rates at the natural sites). Nutrient solutions were applied every two weeks from $15^{\text {th }}$ July to $15^{\text {th }}$ September (in 2010 and 2011, except for the two-week drought periods in the ND treatment in 2011). Controls and D treatments received the same amount of deionized water. The mean temperature in the greenhouse was $17.5^{\circ} \mathrm{C}$ and $19.0{ }^{\circ} \mathrm{C}$, and the mean relative humidity was $77 \%$ and $71 \%$ in the first year and second year of the experiment, respectively (means from July to October in 2010 and May to September in 2011). All pots were randomly relocated every four weeks to avoid position effects.

\subsection{Measurement of Response Variables}

In 2010, the following response variables were measured at the end of the growing season (October): stem diameter (measured $5 \mathrm{~cm}$ above the root collar in N-S and E-W direction), plant height (measured from the root collar to the shoot apex), and total leaf biomass (inferred from the number of leaves per tree individual and the mean biomass of a single leaf, determined after leaf harvest at the end of the experiment). In September 2011, all saplings were harvested and the following variables were measured: stem diameter, plant height, number of dead branches, and number of necrotic leaves (more than two-third of the leaf area with necrotic tissue). The root biomass was sampled by carefully wet sieving roots until soil residues were removed as far as possible. As this cleaning procedure was very laborious, belowground biomass was quantified for a subset of randomly selected saplings only ( $n=28$ per treatment). All biomass samples (shoots, leaves, and roots) were dried to a constant weight at $40^{\circ} \mathrm{C}$, and the following variables were determined: leaf biomass (dry weight $=\mathrm{DW}$ of all leaves), aboveground biomass (DW of shoots and leaves), root biomass DW, and shoot:root ratios (aboveground biomass:belowground biomass ratio; $n=28$ per treatment). Using both years' data, we also calculated the annual stem, height, and total leaf biomass increment.

Analyses of morphological responses were complemented by the analyses of physiological responses (i.e., leaf $C$ and $N$ concentrations, leaf $C: N$ rations, leaf $\delta^{13} C$ signatures; cf. $\left.[24,31]\right)$. To this end, leaf samples (one sample comprised all leaves of a tree individual) were ground in a centrifugal mill (ZM 200, Retsch, Haan, Germany) and re-dried at $40^{\circ} \mathrm{C}$ for 3 days. $\mathrm{C}$ and $\mathrm{N}$ concentrations and $\delta^{13} \mathrm{C}$ signatures were measured using a continuous flow elemental analyzer-isotope mass spectrometer (vario EL cube, Elementar, Hanau, Germany), coupled to an Isoprime Isotope-ratio mass spectrometer (IRMS, Isoprime Ltd., Cheadle Hulme, UK). Isotope signatures were presented in the delta $(\delta)$ notation (in per mil; $\%$ ) as a relative deviation from an international standard (PeeDee Belemnite). The relative precision of repeated analyses of an International Atomic Energy Agency-standard (IAEA-CH-3) was $\pm 0.1 \%$.

To assess the effect of sapling age on shoot:root ratios and leaf $\delta^{13} \mathrm{C}$ signatures, we compared data from the present study with measurements from Dziedek et al. ([31]; one-year-old plants).

\subsection{Statistical Analyses}

We applied linear mixed-effects models (LMMs) to analyze the effects of treatment (control, D, N, $\mathrm{ND)}$ on morphological and physiological responses. To account for variability between forest sites, we used forest site as a random effect. We used the same mixed-model approach to analyze age-related effects (one-year old vs. two-year-old plants) of $\mathrm{N}$ and $\mathrm{D}$ treatments and their interactions on shoot:root ratio and leaf $\delta^{13} \mathrm{C}$ signatures. As some response variables were count data (i.e., number of dead branches and necrotic leaves), we fitted generalized linear mixed-effects models (GLMMs) assuming a Poisson error distribution with a logit link function. We found no indication for overdispersion. The response variables "belowground biomass" and "shoot:root ratio" were log-transformed to meet model assumptions [32]. Model selection (determination of the best-fitting and most parsimonious model) was based on the Akaike information criterion (AIC) using maximum likelihood (ML) estimations and the model with the smallest AIC was chosen as the best-fitting model [33]. Parameter 
estimates of the best-fitting models were based on the restricted maximum likelihood (REML) method. All statistical analyses were conducted with R 3.1.2 (R Project for Statistical Computing; http:/ /www.R-project.org) with the packages lme4 [34] and lmerTest [35].

\section{Results}

\subsection{Effects of $N, D$, and ND Treatments on Two-Year-Old Saplings}

$\mathrm{N}$ and ND treatments caused a significant increase in the aboveground biomass production (in terms of stem increment, leaf biomass increment, and total aboveground biomass), but had no significant effect on the belowground biomass (Table 1 and Table S2). Moreover, the plants' height increment increased in the ND treatment in comparison to the controls. The relative increase in the aboveground biomass allocation resulted in significantly higher shoot:root ratios in the N and ND treatments (Table S2). Branch dieback was significant only in the ND treatment $(p=0.006)$, whereas N fertilization reduced the number of necrotic leaves (negative estimate; Table 1). $\mathrm{N}$ fertilization caused a distinct increase in $\mathrm{N}$ concentrations, which in turn resulted in decreasing $\mathrm{C}: \mathrm{N}$ ratios (Tables 1 and S2). Leaf $\delta^{13} \mathrm{C}$ signatures were not significantly affected by $\mathrm{N}$ fertilization. $\mathrm{D}$ treatments had no effect on morphological responses, but caused decreasing values for $\mathrm{C}$ concentrations, $\mathrm{N}$ concentrations, and leaf $\delta^{13} \mathrm{C}$ signatures (Tables 1 and S2).

\subsection{Effects of Sapling-Age}

On average, one-year-old plants showed significantly higher shoot:root ratios than two-year-old plants (Table 2; $p<0.001$ ). In the controls, shoot:root ratios decreased from 1.78 in the first year to 1.20 in the second year (Figure 2a). The effects of the $\mathrm{N}$ treatments on shoot:root ratios were not affected by plant age (i.e., no significant $\mathrm{N} \times$ Age interaction; Table 2). This indicates that $\mathrm{N}$ fertilization caused an increase in shoot:root ratios irrespective of the plants age.
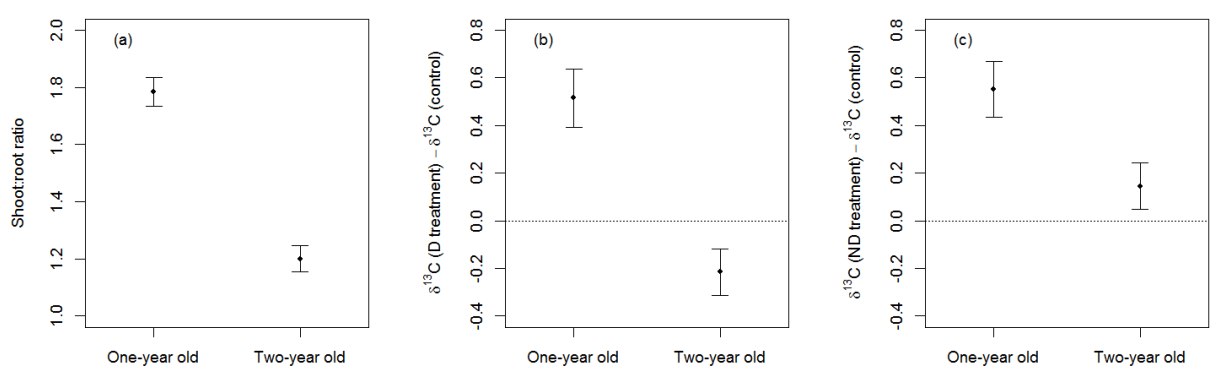

Figure 2. (a) Shoot:root ratios (mean $\pm 1 \mathrm{SE}$ ) of one-year-old and two-year-old Fagus sylvatica plants in the control treatment. Age-related differences are significant at $\alpha=0.001$. Differences in tissue $\delta^{13} \mathrm{C}$ signatures (mean $\pm 1 \mathrm{SE}$ ) between $(\mathbf{b})$ drought treatments $(\mathrm{D})$ and the control $(p<0.001)$ and (c) combined nitrogen and drought treatments (ND) and the control $(p=0.008)$ of one-year-old and two-year-old Fagus sylvatica plants.

In addition, we found age-related responses of leaf $\delta^{13} \mathrm{C}$ signatures to $\mathrm{D}$ and ND treatments, indicated by a significant $\mathrm{D} \times$ Age interaction for leaf $\delta^{13} \mathrm{C}$ signatures (Table 2). Whereas $\mathrm{D}$ treatments caused an increase in leaf $\delta^{13} \mathrm{C}$ values of one-year-old plants by about $0.53 \%$ (from $-29.36 \%$ o to $-28.83 \%$ ), leaf $\delta^{13} \mathrm{C}$ values of two-year-old plants decreased by about $0.19 \%$ (from $-29.05 \%$ o to $-29.24 \%$; Figure 2b). In the ND treatment, we found a significant increase in leaf $\delta^{13} \mathrm{C}$ values by about $0.57 \%$ for one-year-old plants (from $-29.36 \%$ to $-28.79 \%$ ), whereas shifts in $\delta^{13} \mathrm{C}$ values were non-significant for two-year-old plants (increase by about $0.09 \%$ from $-29.05 \%$ to $-28.96 \%$; Figure 2c). Importantly, $\mathrm{N}$ treatments strengthened an increase in leaf $\delta^{13} \mathrm{C}$ signatures following $\mathrm{D}$ treatments, indicated by significant $\mathrm{D} \times \mathrm{N}$ interaction (and a positive estimate) for both one-year-old and two-year-old plants $(p=0.042)$. 
Table 1. Results of mixed-effects models (LMM and GLMM) for treatment effects in response to morphological and physiological variables. Abbreviations of treatments: $\mathrm{D}=$ drought treatment, $\mathrm{N}=$ nitrogen treatment, $\mathrm{ND}=$ combined nitrogen and drought treatment; significant effects $(p<0.05)$ are indicated in bold.

\begin{tabular}{|c|c|c|c|c|c|c|c|c|c|c|c|c|}
\hline Morphological Variables & \multicolumn{2}{|c|}{ Stem Increment } & \multicolumn{4}{|c|}{ Height Increment } & \multicolumn{2}{|c|}{$\begin{array}{l}\text { Leaf Biomass } \\
\text { Increment }\end{array}$} & \multicolumn{4}{|c|}{ Aboveground Biomass } \\
\hline & Estimate & $t$-value & $p$-value & Estimate & $t$-value & $p$-value & Estimate & $t$-value & $p$-value & Estimate & $t$-value & $p$-value \\
\hline Intercept & 1.867 & 16.828 & $<0.001$ & 3.837 & 3.617 & 0.004 & 2.546 & 9.986 & $<0.001$ & 18.121 & 19.998 & $<0.001$ \\
\hline $\mathrm{D}^{\mathrm{I}}$ & 0.026 & 0.260 & 0.793 & 0.048 & 0.054 & 0.957 & 0.158 & 1.158 & 0.248 & 0.609 & 0.709 & 0.479 \\
\hline $\mathrm{N}$ & 0.566 & 5.649 & $<0.001$ & 2.021 & 2.292 & 0.023 & 0.397 & 2.932 & 0.004 & 2.712 & 3.170 & 0.002 \\
\hline ND & 0.567 & 5.675 & $<0.001$ & 2.599 & 2.956 & 0.003 & 0.461 & 3.413 & $<0.001$ & 3.593 & 4.211 & $<0.001$ \\
\hline Morphological Variables & \multicolumn{2}{|c|}{$\begin{array}{l}\text { Belowground } \\
\text { Biomass }\end{array}$} & \multicolumn{4}{|c|}{ Shoot:Root Ratio } & \multicolumn{2}{|c|}{$\begin{array}{l}\text { No. of Necrotic } \\
\text { Leaves }\end{array}$} & \multicolumn{4}{|c|}{ No. of Dead Branches } \\
\hline & Estimate & $t$-value & $p$-value & Estimate & $t$-value & $p$-value & Estimate & $\chi^{2}$ & $p$-value & Estimate & $\chi^{2}$ & $p$-value \\
\hline Intercept & 2.669 & 41.668 & $<0.001$ & 0.073 & 3.690 & 0.002 & 0.550 & 2.363 & 0.018 & 0.072 & -0.270 & 0.787 \\
\hline $\mathrm{D}^{1}$ & 0.047 & 0.599 & 0.550 & 0.008 & -0.375 & 0.709 & 0.464 & 1.675 & 0.094 & 0.079 & -0.386 & 0.700 \\
\hline $\mathrm{N}$ & 0.068 & 0.866 & 0.389 & 0.059 & 2.857 & 0.005 & -0.620 & -2.130 & 0.033 & 0.216 & 1.101 & 0.270 \\
\hline ND & 0.109 & 0.079 & 0.169 & 0.043 & 2.061 & 0.041 & -0.330 & -1.163 & 0.245 & 0.512 & 2.724 & 0.006 \\
\hline Physiological Variables & \multicolumn{2}{|c|}{$\begin{array}{c}\text { C Concentration } \\
\text { Leaves }\end{array}$} & \multicolumn{4}{|c|}{$\begin{array}{c}\text { N Concentration } \\
\text { Leaves }\end{array}$} & \multicolumn{2}{|c|}{ C:N Ratio } & \multicolumn{4}{|c|}{ Leaf $\delta^{13} \mathrm{C}$ Signature } \\
\hline Intercept & $\begin{array}{c}\text { Estimate } \\
463.205\end{array}$ & $\begin{array}{c}t \text {-value } \\
1.987\end{array}$ & $\begin{array}{c}p \text {-value } \\
<0.001\end{array}$ & $\begin{array}{c}\text { Estimate } \\
15.413\end{array}$ & $\begin{array}{c}t \text {-value } \\
27.799\end{array}$ & $\begin{array}{c}p \text {-value } \\
<0.001\end{array}$ & $\begin{array}{c}\text { Estimate } \\
30.777\end{array}$ & $\begin{array}{c}t \text {-value } \\
29.853\end{array}$ & $\begin{array}{c}p \text {-value } \\
<0.001\end{array}$ & $\begin{array}{c}\text { Estimate } \\
29.049\end{array}$ & $\begin{array}{l}t \text {-value } \\
-167.820\end{array}$ & $\begin{array}{l}p \text {-value } \\
<0.001\end{array}$ \\
\hline D & -3.738 & 2.931 & 0.004 & -1.354 & -4.296 & $<0.001$ & 2.420 & 4.634 & $<0.001$ & -0.197 & -2.175 & 0.030 \\
\hline $\mathrm{N}$ & -2.466 & 1.934 & 0.054 & 3.138 & 9.954 & $<0.001$ & -5.380 & 10.302 & $<0.001$ & -0.094 & -0.134 & 0.302 \\
\hline ND & -2.482 & 1.945 & 0.053 & 2.557 & 8.107 & $<0.001$ & -4.718 & -9.031 & $<0.001$ & 0.083 & 0.920 & 0.358 \\
\hline
\end{tabular}


Table 2. Best-fitting mixed-effects models for (a) shoot:root ratio and (b) leaf $\delta^{13} \mathrm{C}$ signatures of Fagus sylvatica saplings. Shoot:root ratios and leaf $\delta^{13} \mathrm{C}$ signatures were modelled as a function of the saplings' age (one-year old vs. two-year-old plants), drought treatments (D, ND), nitrogen treatments $(\mathrm{N}, \mathrm{ND})$, and their interactions. The best-fitting model was selected using the Akaike information criterion (AIC).

\begin{tabular}{lrrr}
\hline Fixed Effects & Estimate & $t$-Value & $p$-Value \\
\hline (a) Shoot:root ratio & & & \\
Intercept & 1.747 & 22.185 & $<0.001$ \\
D & 0.023 & 4.649 & $<0.001$ \\
N & 0.089 & 2.078 & 0.038 \\
Age (1 year vs. 2 years) & -0.456 & -4.392 & $<0.001$ \\
D $\times$ Age & -0.258 & -2.621 & 0.009 \\
\hline (b) Leaf $\delta^{13}$ C signature & & & \\
Intercept & -29.688 & -159.014 & $<0.001$ \\
D & 0.442 & 5.431 & $<0.001$ \\
N & -0.034 & -0.516 & 0.606 \\
Age (1 year vs. 2 years) & 1.058 & 8.188 & $<0.001$ \\
D $\times$ N & 0.191 & 2.035 & 0.042 \\
D $\times$ Age & -0.546 & -5.804 & $<0.001$ \\
\hline
\end{tabular}

\section{Discussion and Conclusions}

\subsection{Treatment ( $N, D, N D)$ Effects on Sapling Growth}

Beech saplings significantly increased their aboveground investments in N and ND treatments and hence followed the "resource optimization hypothesis" [36], according to which plants increase their aboveground biomass allocation as a result of improved nutrient supply. This observation is in agreement with other studies $[17,18,37,38]$, and was also mirrored by increased shoot:root ratios in the N and ND treatments. However, only plants from the ND treatment showed a significant biomass dieback. This finding supports our first hypothesis ("N-fertilized plants exhibit higher drought sensitivity") and suggests that combined effects of $\mathrm{N}$ fertilization and drought may adversely affect the vitality of beech saplings. This interpretation is supported by the finding that $\mathrm{N}$ treatments strengthened the effect of drought on leaf $\delta^{13} \mathrm{C}$ signatures $(\mathrm{D} \times \mathrm{N}$ interaction; Table 2). This might be explained with the observed shifts in biomass allocation patterns (i.e., increasing shoot:root ratios), as has also been documented by other studies. $[39,40]$. An indication of drought stress based on the plants' leaf $\delta^{13} \mathrm{C}$ signatures in the ND treatment was particularly pronounced for one-year-old plants (see paragraph on "effects of sapling age"). We cannot rule out the possibility that other factors, such as nutrient imbalances or a failure of photoassimilate transport, may have also contributed to the dieback of branches of two-year-old plants, because these factors are impaired by $\mathrm{N}$ fertilization [41].

\subsection{Effects of Sapling Age}

Comparisons of leaf $\delta^{13} \mathrm{C}$ signatures showed that plant responses to treatments were strongly influenced by sapling age. This supports our second hypothesis that one-year-old plants would react more sensitively to treatments than two-year-old plants, particularly with regard to drought events. We hypothesize that differences in drought sensitivity were mainly related to the plants' shoot:root ratios [22], which significantly differed for one-year-old and two-year-old beech saplings (i.e., two-year-old plants showed relatively higher belowground investments than one-year-old plants). As a consequence of these age-related shifts in biomass allocation patterns (i.e., apparent plasticity; according to Weiner [15]), two-year-old plants may be less drought sensitive and may experience less constraints in their water supply, particularly in periods of drought $[42,43]$. This interpretation is supported by the finding that leaf $\delta^{13} \mathrm{C}$ signatures of one-year-old plants increased by $0.53 \%$ and $0.57 \%$ 
in the D and ND treatment, respectively, whereas two-year-old plants showed no significant shifts or even decreasing values in leaf $\delta^{13} \mathrm{C}$ signatures in response to the ND and D treatments, respectively.

Given that the biomass allocation patterns of many plant species follow allometric trajectories and are therefore a function of plant age [15], our findings on age-related responses might have general implications for predictions of plant responses to environmental stressors such as climate or atmospheric changes. In forest ecosystems, for example, biomass allocation patterns strongly depend on tree age [44], but relationships between the trees' life-stages and their sensitivity to climate and atmospheric changes have not been well investigated or are even unknown [45]. Ettinger and HilleRisLambers [46] found that climate change-related tree mortality in forest ecosystems was strongly affected by stand development processes, and effects of decreasing precipitation or increasing temperatures on tree growth significantly decreased with stand age. A study by Luo and Chen [45] confirmed that climate change-associated increases in tree mortality were significantly higher in young compared to old forests due to the higher sensitivity of young trees to regional warming and drought. Thus, observations from mature forest stands might underestimate climate change effects on tree mortality. Luo and Chen [45] concluded that life-stage related analyses of tree growth are crucial to better understand and predict forest responses to climate change. This might also apply to an assessment of interaction effects of drought and $\mathrm{N}$ deposition on tree growth: given that one-year-old seedlings have the highest shoot:root ratios (according to age-related allometric trajectories; [15]) and that $\mathrm{N}$ fertilization further increases shoot:root ratios (according to the resource optimization hypothesis), then $\mathrm{N}$-fertilized one-year-old seedlings should exhibit the highest sensitivity to drought events (also suggested by the significant $\mathrm{D} \times \mathrm{N}$ interaction for leaf $\delta^{13}$ signatures). This conclusion is supported by the experiments of Dziedek et al. [31], which showed that a combination of $\mathrm{N}$ fertilization and drought negatively affected the total biomass production and strongly increased the formation of necrotic leaf tissue.

In conclusion, our experiments provided evidence that nitrogen fertilization has the potential to increase the drought sensitivity of beech saplings due to its impact on biomass partitioning, with consequences for the plants' shoot:root ratios (i.e., plastic allometry of tree saplings). However, this increase in drought sensitivity is confounded with sapling age, because sapling development seems to follow allometric growth trajectories in which partitioning patterns are also life-stage dependent (i.e., apparent plasticity of tree saplings). As a consequence, predictions of tree growth responses to atmospheric and climate changes should consider the effects related to both the plastic allometry and apparent plasticity of a tree species' development. We are aware that greenhouse experiments are limited with regard to a generalization of findings, and our study does not allow us to directly infer growth response of naturally regenerated trees to global change effects. However, allometric growth trajectories should also apply to naturally regenerated tree saplings. This would indicate that assessments of tree growth responses to global change should include life-stage related shifts in a tree's sensitivity to co-occurring global change drivers.

Supplementary Materials: The following are available online at http://www.mdpi.com/1999-4907/8/3/91/s1, Table S1: Site characteristics (from Dziedek et al. [31]), Table S2: Summary of treatment effects on the response variables measured, Table S3: Data for two-year-old trees, Table S4: Data for one-year-old and two-year-old trees (comparisons of shoot:root ratios and leaf $\delta^{13}$ signatures). References $[47,48]$ are cited in the supplementary materials").

Acknowledgments: This study was conducted in cooperation with the Johann Heinrich von Thünen-Institute (former Institute of World Forestry) in Hamburg. It was financially supported by the Friedrich Ebert Foundation (Bonn, Germany).

Author Contributions: C.D., W.H., L.C., E.M., and G.v.O. conceived of the study and study design, and performed parts of the research. All authors contributed to data analyses, and to the writing of the paper.

Conflicts of Interest: The authors declare no conflict of interest. 


\section{References}

1. McLauchlan, K.K.; Craine, J.M. Species-specific trajectories of nitrogen isotopes in Indiana hardwood forests, USA. Biogeoscience 2012, 9, 867-874. [CrossRef]

2. Pretzsch, H.; Biber, P.; Schütze, G.; Uhl, E.; Rötzer, T. Forest stand growth dynamics in Central Europe have accelerated since 1870. Nat. Commun. 2014, 5, 4967. [CrossRef] [PubMed]

3. Sala, O.E.; Chapin, F.S., III; Armesto, J.J.; Berlow, E.; Bloomfield, J.; Dirzo, R.; Huber-Sanwald, E.; Huenneke, L.F.; Jackson, R.B.; Kinzig, A.; et al. Global biodiversity scenarios for the year 2100. Science 2000, 287, 1770-1774. [CrossRef] [PubMed]

4. $\quad$ IPCC. Climate Change 2013: The Physical Science Basis. Contribution of Working Group I to the Fifth Assessment Report of the Intergovernmental Panel on Climate Change; Cambridge University Press: New York, NY, USA, 2013.

5. Allen, C.D.; Macalady, A.K.; Chenchouni, H.; Bachelet, D.; McDowell, N.; Vennetier, M.; Kitzberger, T.; Rigling, A.; Breshears, D.D.; Hogg, E.H.; et al. A global overview of drought and heat-induced tree mortality reveals emerging climate change risks for forests. For. Ecol. Manag. 2010, 259, 660-684. [CrossRef]

6. Scherer-Lorenzen, M. The functional role of biodiversity in the context of global change. In Forests and Global Change; Coomes, D.A., Burslem, D.F.R.P., Simonson, W.D., Eds.; Cambridge University Press: Cambridge, UK, 2014; pp. 195-237.

7. Jucker, T.; Avăcăriței, D.; Bărnoaiea, I.; Duduman, G.; Bouriaud, O.; Coomes, D.A. Climate modulates the effects of tree diversity on forest productivity. J. Ecol. 2016, 104, 388-398. [CrossRef]

8. Galloway, J.N.; Dentener, F.J.; Capone, D.G.; Boyer, E.W.; Howarth, R.W.; Seitzinger, S.P.; Asner, G.P.; Cleveland, C.C.; Green, P.A.; Holland, E.A.; et al. Nitrogen cycles: Past, present, and future. Biogeochem 2004, 70, 153-226. [CrossRef]

9. Fowler, D.; Coyle, M.; Skiba, U.; Sutton, M.A.; Cape, J.N.; Reis, S.; Sheppard, L.J.; Jenkins, A.; Grizzetti, B.; Galloway, J.N.; et al. The global nitrogen cycle in the twenty-first century. Phil. Trans. R. Soc. B 2013, 368, 20130164. [CrossRef] [PubMed]

10. Bobbink, R.; Hornung, M.; Roelofs, J.G.M. The effects of air-borne nitrogen pollutants on species diversity in natural and semi-natural European vegetation. J. Ecol. 1998, 86, 717-738. [CrossRef]

11. Stevens, C.J.; Dise, N.B.; Gowing, D.J.G.; Mountford, J.O. Loss of forb diversity in relation to nitrogen deposition in the UK: Regional trends and potential controls. Glob. Chang. Biol. 2006, 12, 1823-1833. [CrossRef]

12. Greaver, T.L.; Clark, C.M.; Compton, J.E.; Vallano, D.; Talhelm, A.F.; Weaver, C.P.; Band, L.E.; Baron, J.S.; Davidson, E.A.; Tague, C.L.; et al. Key ecological responses to nitrogen are altered by climate change. Nat. Clim. Chang. 2016, 6, 836-843. [CrossRef]

13. Zavaleta, E.S.; Shaw, M.R.; Chiariello, N.R.; Mooney, H.A.; Field, C.B. Additive effects of simulated climate changes, elevated $\mathrm{CO}_{2}$, and nitrogen deposition on grassland diversity. Proc. Natl. Acad. Sci. USA 2003, 100, 7650-7654. [CrossRef] [PubMed]

14. Gessler, A.; Schaub, M.; McDowell, N.G. The role of nutrients in drought-induced tree mortality and recovery. New Phytol. 2016. [CrossRef] [PubMed]

15. Weiner, J. Allocation, plasticity and allometry in plants. Perspect. Plant Ecol. Evol. Syst. 2004, 6, $207-215$. [CrossRef]

16. Turner, M.M.; Henry, H.A.L. Interactive effects of warming and increased nitrogen deposition on ${ }^{15} \mathrm{~N}$ tracer retention in a temperate old field: Seasonal trends. Glob. Chang. Biol. 2009, 15, 2885-2893. [CrossRef]

17. Friedrich, U.; von Oheimb, G.; Kriebitzsch, W.U.; Schlesselmann, K.; Weber, M.S.; Härdtle, W. Nitrogen deposition increases susceptibility to drought-Experimental evidence with the perennial grass Molinia caerulea L. Moench. Plant Soil 2012, 353, 59-71. [CrossRef]

18. Meyer-Grünefeldt, M.; Friedrich, U.; Klotz, M.; von Oheimb, G.; Härdtle, W. Nitrogen deposition and drought events have non-additive effects on plant growth-evidence from greenhouse experiments. Plant Biosyst. 2015, 149, 424-432. [CrossRef]

19. Dziedek, C.; Härdtle, W.; von Oheimb, G.; Fichtner, A. Nitrogen addition enhances drought sensitivity of young deciduous tree species. Front. Plant Sci. 2016, 7, 1100. [CrossRef] [PubMed]

20. Weiner, J.; Thomas, S.C. The nature of tree growth and the "age-related decline in forest productivity". Oikos 2001, 94, 374-376. [CrossRef] 
21. Thomas, S.C. Age-related changes in tree growth and functional biology: The role of reproduction. In Sizeand Age-Related Changes in Tree Structure and Function; Meinzer, F.C., Lachenbruch, B., Dawson, T.E., Eds.; Springer: Berlin, Germany, 2011; pp. 33-64.

22. Brunner, I.; Herzog, C.; Dawes, M.A.; Arend, M.; Sperisen, C. How tree roots respond to drought. Front. Plant Sci. 2015, 6, 547. [CrossRef] [PubMed]

23. Ellenberg, H.; Leuschner, C. Vegetation Mitteleuropas mit den Alpen; Ulmer: Stuttgart, Germany, 2010.

24. Rose, L.; Leuschner, C.; Köckemann, B.; Buschmann, H. Are marginal beech (Fagus sylvatica L.) provenances a source for drought tolerant ecotypes? Eur. J. For. Res. 2009, 128, 335-343. [CrossRef]

25. Magri, D.; Vendramin, G.G.; Comps, B.; Dupanloup, I.; Geburek, T.; Gomory, D.; Latalowa, M.; Litt, T.; Paule, L.; Roure, J.M.; et al. A new scenario for the Quaternary history of European beech populations: Palaeobotanical evidence and genetic consequences. New Phytol. 2006, 171, 199-221. [CrossRef] [PubMed]

26. Widmer, A.; Lexer, C. Glacial refugia: Sanctuaries for allelic richness, but not for gene diversity. Trends Ecol. Evol. 2001, 16, 267-269. [CrossRef]

27. Hampe, A.; Petit, R.J. Conserving biodiversity under climate change: The rear edge matters. Ecol. Lett. 2005, 8, 461-467. [CrossRef] [PubMed]

28. Jump, A.S.; Hunt, J.; Penuelas, J. Rapid climate change-related growth decline at the southern range edge of Fagus sylvatica. Glob. Chang. Biol. 2006, 12, 2163-2174. [CrossRef]

29. Hampe, A.; Jump, A.S. Climate relicts: Past, present, future. Annu. Rev. Ecol. Evol. Syst. 2011, 42, $313-333$. [CrossRef]

30. Farquhar, G.D.; Ehleringer, J.R.; Hubick, K.T. Carbon isotope discrimination and photosynthesis. Annu. Rev. Plant Physiol. Plant Mol. Biol. 1989, 40, 503-537. [CrossRef]

31. Dziedek, C.; von Oheimb, G.; Calvo, L.; Fichtner, A.; Kriebitzsch, W.U.; Marcos, E.; Pitz, W.T.; Härdtle, W. Does excess nitrogen supply increase the drought sensitivity of European beech (Fagus sylvatica L.) seedlings? Plant Ecol. 2016, 217, 393-405. [CrossRef]

32. Crawley, M.J. The R Book; Wiley: Chichester, UK, 2007.

33. Burnham, K.P.; Anderson, D.R. Model selection and Multimodel Inference: A Practical Information-Theoretical Approach; Springer: New York, NY, USA, 2002.

34. Bates, D.; Maechler, M.; Bolker, B.; Walker, S. 2014. lme4: Linear Mixed-Effects Models Using Eigen and S4. R Package Version 1.1-6. Available online: http:/ /CRAN.R-project.org/package=lme4 (accessed on 18 November 2016).

35. Kuznetsova, A.; Brockhoff, P.B.; Christensen, R.H.B. lmerTest: Tests for Random and Fixed Effects for Linear Mixed Effect Models Lmer Objects of lme4 Package. R Package Version 2.0-6. Available online: http:/ /CRAN.R-project.org/package=lmerTest (accessed on 18 November 2016).

36. Ågren, G.I.; Franklin, O. Root: Shoot ratios, optimization and nitrogen productivity. Ann. Bot. 2003, 92, 795-800. [CrossRef] [PubMed]

37. Müller, I.; Schmid, B.; Weiner, J. The effect of nutrient availability on biomass allocation patterns in 27 species of herbaceous plants. Perspect. Plant Ecol. Evol. Syst. 2000, 3, 115-127. [CrossRef]

38. Potocic, N.; Seletkovic, I.; Cater, M.; Cosic, T.; Sango, M.; Vedris, M. Ecophysiological response of sun-exposed Common Beech (Fagus sylvatica L.) seedlings under different fertilization levels. Sumarski List 2009, 133, 289-300.

39. Högberg, P.; Johannisson, C.; Hallgren, J.E. Studies of ${ }^{13} \mathrm{C}$ in the foliage reveal interactions between nutrients and water in forest fertilization experiments. Plant Soil 1993, 152, 207-214. [CrossRef]

40. Gordon, C.; Woodin, S.J.; Alexander, I.J.; Mullins, C.E. Effects of increased temperature, drought and nitrogen supply on two upland perennials of contrasting functional type: Calluna vulgaris and Pteridium aquilinum. New Phytol. 1999, 142, 243-258. [CrossRef]

41. Jokela, A.; Back, J.; Huttunen, S.; Jalkanen, R. Excess nitrogen-fertilization and the structure of Scots-Pine needles. Eur. J. For. Pathol. 1995, 25, 109-124. [CrossRef]

42. Hamp, R.; Shi, L.; Guttenberger, M.; Nehls, U. Mykorrhizierung und Stresstoleranz von Ökotypen der Buche (Fagus sylvatica L.): "Conventwaldprojekt". Forschungsbericht 1999. FZKA-BWPLUS.

43. Meier, I.C.; Leuschner, C. Belowground drought response of European beech: Fine root biomass and carbon partitioning in 14 mature stands across a precipitation gradient. Glob. Chang. Biol. 2008, 14, 2081-2095. [CrossRef] 
44. Huet, S.; Forgeard, F.; Nys, C. Above- and belowground distribution of dry matter and carbon biomass of Atlantic beech (Fagus sylvatica L.) in a time sequence. Ann. For. Sci. 2004, 61, 683-694. [CrossRef]

45. Luo, Y.; Chen, H.Y.H. Observations from old forests underestimate climate change effects on tree mortality. Nat. Commun. 2013, 4, 1655. [CrossRef] [PubMed]

46. Ettinger, A.K.; HilleRisLambers, J. Climate isn't everything: Competitive interactions and variation by life stage will also affect range shifts in a warming world. Am. J. Bot. 2013, 100, 1344-1355. [CrossRef] [PubMed]

47. Marcos, E.; Calvo, L.; Marcos, J.A.; Taboada, A.; Tarrega, R. Tree effects on the chemical topsoil features of oak, beech and pine forests. Eur. J. For. Res. 2010, 129, 25-30. [CrossRef]

48. Rivas-Martinez, S. Estudio de la vegetacion y flora de las Sierras de Guadarrama y Gredos. An. del Inst. Bot. A.J. Cavanilles 1963, 21, 5-330.

(C) 2017 by the authors. Licensee MDPI, Basel, Switzerland. This article is an open access article distributed under the terms and conditions of the Creative Commons Attribution (CC BY) license (http:/ / creativecommons.org/licenses/by/4.0/). 